BMJ Open Ophthalmology

\section{In vitro efficacy of topical ophthalmic antiseptics against SARS-CoV-2}

To cite: Felfeli T, Kasloff SB, Krishnan J, et al. In vitro efficacy of topical ophthalmic antiseptics against SARS-CoV-2. BMJ Open Ophthalmology 2021;6:e000765. doi:10.1136/ bmjophth-2021-000765

- Additional supplemental material is published online only. To view, please visit the journal online (http://dx.doi. org/10.1136/bmjophth-2021000765).
Check for updates

C Author(s) (or their employer(s)) 2021. Re-use permitted under CC BY-NC. No commercial re-use. See rights and permissions. Published by BMJ.

For numbered affiliations see end of article.

Correspondence to Dr Tina Felfeli; tina.felfeli@mail. utoronto.ca
Shedding of SARS-CoV-2 in tears of patients with COVID-19 has been reported, ${ }^{12}$ which could serve as a source of infection for healthy individuals, including healthcare providers. The current standard antiseptic solutions used in ophthalmology in the setting of inoffice procedures and operating rooms include povidone-iodine (PVI) $5 \%$ and chlorhexidine gluconate (CHX) $0.1 \%$ or $0.05 \%$, which are at concentrations that are lower than those used in other surgical specialties. Although laboratory and clinical studies to date have aimed to evaluate the virucidal benefits of routine PVI use for ophthalmic surgeries, ${ }^{3}$ currently there are no established guidelines regarding the optimal contact time and efficacy of varying dilutions as well as comparisons with other formulations such as CHX. Rigorous evaluation of the efficacy of virucidal agents for disinfecting ocular surface of potentially infected patients with SARS-CoV-2 is critical in mitigating the risk of transmission.

In the current study, we evaluated the virucidal efficacy and contact times for commonly used ophthalmic concentrations of PVI and CHX against SARS-CoV-2 using Vero E6 cells as indicator cell lines for residual viable virus based on previously established methodologies (online supplemental appendix). ${ }^{4-6}$ PVI $(5 \%$ weight per volume, w/v) and CHX $(0.05 \%$ and $0.1 \% \mathrm{w} / \mathrm{v}$ ) were tested at full strength. Fifty microlitres of ophthalmic formulations were added to $10 \mu \mathrm{L}$ of a SARS-CoV-2 suspension (viral transport media) and incubated at room temperature for varying contact times. A total of three experiments were conducted for PVI and CHX, each including three biological replicates per time point. Individual viral titres for each biological replicate were calculated based on five replicate wells per dilution. Viable residual SARS-CoV-2 was quantified by the Reed-Muench median tissue culture infectious dose $\left(\mathrm{TCID}_{50}\right)$ procedure in Vero E6 cells. ${ }^{7}$ Additional efficacy testing using 1:4 and 1:16 dilutions in phosphate buffered saline were performed in order to mimic clinical settings where dilution of the formulations occurs as a result of mixing with patients' ocular secretions. Cytotoxicity of residual PVI and CHX was predetermined at all test concentrations using uninfected Vero E6 cells.

No SARS-CoV-2 was detected with PVI at full strength and 1:4 dilution after $60 \mathrm{~s}, 5 \mathrm{~min}$ and $10 \mathrm{~min}$ of contact time (figure 1). The 1:16 PVI dilution substantially decreased viral titres after $60 \mathrm{~s}$ of contact time $(4.45$, SD 0.44 vs 0.12 , SD $0.24 \log _{10} \mathrm{TCID}_{50} / \mathrm{mL}, 95 \%$ CI of difference 3.53 to $5.13, \mathrm{p}<0.001)$. No virus was recovered from the inoculated suspensions after 5 and $10 \mathrm{~min}$ of contact time with the 1:16 PVI dilution. Full strength CHX $0.1 \%\left(3.99\right.$, SD 0.08 vs 3.74 , SD $0.10 \log _{10}$ TCID $_{50} / \mathrm{mL}, 95 \%$ CI 0.04 to $0.46, \mathrm{p}=0.03$ ) and CHX $0.05 \%$ (4.3, SD 0.5 vs 4.53 , SD $0.44 \log _{10} \mathrm{TCID}_{50} / \mathrm{mL}, 95 \%$ CI -1.30 to $0.84, \mathrm{p}=0.58)$ concentrations did not result in SARS-CoV-2 inactivation even after 30 min of contact time.

The findings from this in vitro study demonstrate that PVI at commonly used ophthalmic concentration of $5 \%$ has greater virucidal activity than CHX against SARS-CoV-2 in inoculated suspensions, with CHX proving to be ineffective at full concentration of $0.1 \%$ even after $30 \mathrm{~min}$ of contact time. The virucidal benefits of routine PVI in reducing patients' ocular surface viral load may be effective at 1:16 of the initial concentration with only $60 \mathrm{~s}$ of contact time. It is important to note that $\mathrm{CHX} 0.1 \% \mathrm{w} / \mathrm{v}$ is at the upper limit of the concentration commonly used in ophthalmic procedure settings. These findings are in keeping with previous findings which have shown the efficacy of PVI in managing upper respiratory 


\section{A Povidone-lodine $5 \% \mathrm{w} / \mathrm{v}, 1: 4$ dilution}

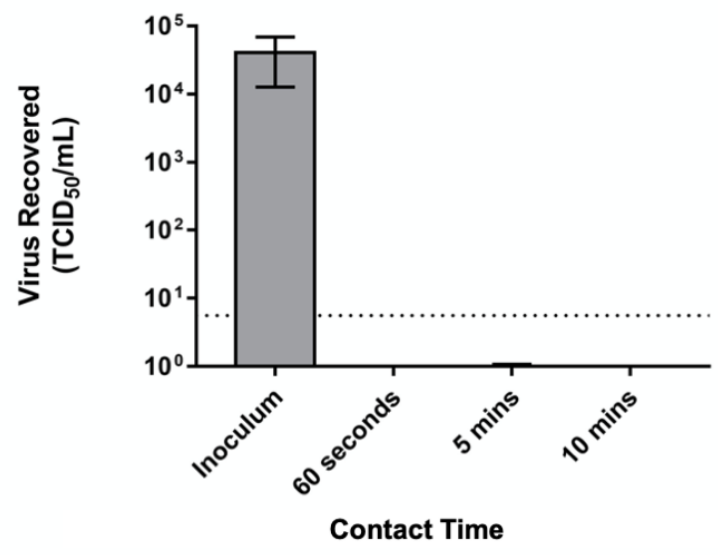

C Chlorhexidine Gluconate $0.1 \%$ w/v

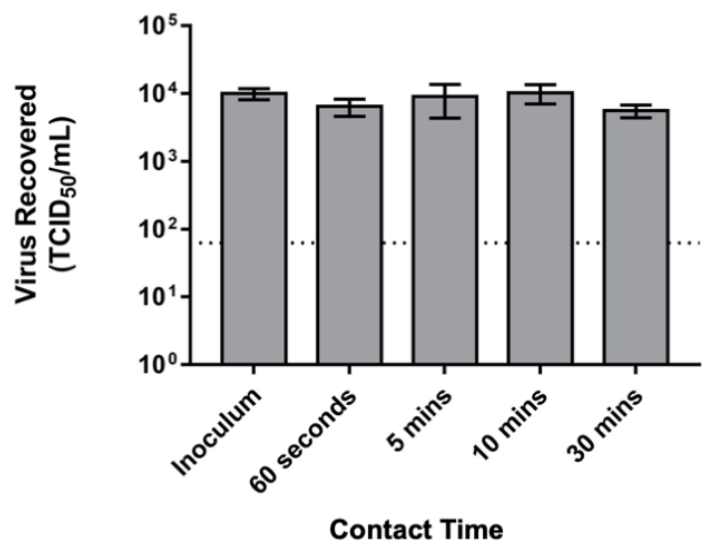

B Povidone-lodine 5\% w/v, 1:16 dilution

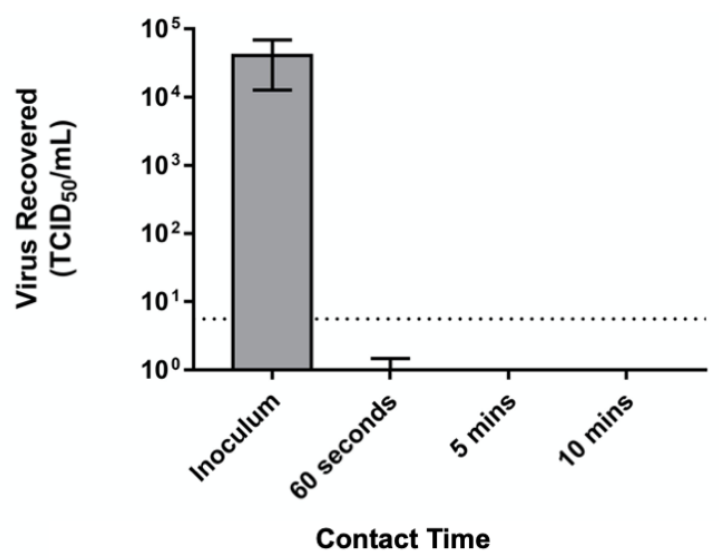

D Chlorhexidine Gluconate $\mathbf{0 . 0 5 \%}$ w/v

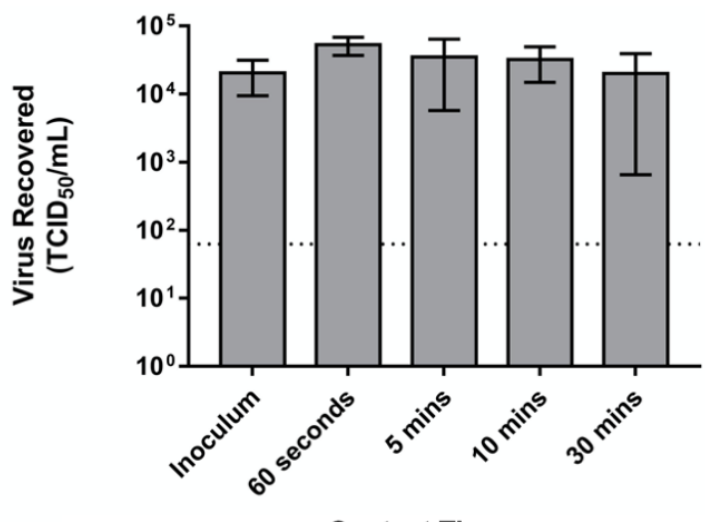

Contact Time

Figure 1 Virucidal efficacy of ophthalmic formulations of povidone-iodine (PVI) and chlorhexidine gluconate (CHX) against SARS-CoV-2. (A and B) Mean $( \pm S D$ ) titre of the positive control (inoculum, 0 min contact time) and the postneutralisation samples $(60 \mathrm{~s}, 5 \mathrm{~min}$ and $10 \mathrm{~min}$ contact time) with PVI $5 \%$ at $1: 4$ and 1:16 dilutions, respectively. (C and D) Mean $( \pm$ SD) titre of the positive control (inoculum, $0 \mathrm{~min}$ contact time) and the postneutralisation samples $(60 \mathrm{~s}, 5 \mathrm{~min}, 10 \mathrm{~min}$ and $30 \mathrm{~min}$ of contact time) with $\mathrm{CHX} 0.1 \%$ and $0.05 \%$, respectively. The horizontal dashed lines indicate the limit of detection (LOD) of the assay. Note that the LOD is higher for $\mathrm{CHX}\left(1.8 \log _{10} \mathrm{TCID}_{50} / \mathrm{mL}\right)$ than PVI $\left(0.8 \log _{10} \mathrm{TCID}_{50} / \mathrm{mL}\right)$ due to its cytotoxicity on Vero E6 cells. $\mathrm{TCID}_{50}$, tissue culture infectious dose; $\mathrm{w} / \mathrm{v}$, weight per volume.

tract infections and suggested the use of PVI on the sinonasal and oral mucosa against the transmission of SARS-CoV-2. ${ }^{8}$ Overall, this study has important implications for clinicians when selecting an ophthalmic solution for routine procedures that reduces transmissibility of SARS-CoV-2 via ocular secretions among patients and healthcare providers. The adoption of guidelines for ophthalmic surgeries such as lacrimal surgeries using PVI may be useful in decreasing viral burden in the setting of the COVID-19 pandemic and other viral infections.

\section{Author affiliations}

${ }^{1}$ Department of Ophthalmology and Vision Sciences, University of Toronto, Toronto, Ontario, Canada

${ }^{2}$ Dalla Lana School of Public Health, University of Toronto, Toronto, Ontario, Canada ${ }^{3}$ Kensington Vision and Research Centre, Kensington Eye Institute, University of Toronto, Toronto, Ontario, Canada
${ }^{4}$ J.C. Wilt Infectious Diseases Research Centre, Public Health Agency of Canada Ontario Manitoba Saskatchewan Regional Office, Winnipeg, Manitoba, Canada ${ }^{5}$ Canadian Science Centre for Human and Animal Health, Winnipeg, Manitoba, Canada

${ }^{6}$ Department of Microbiology, Mount Sinai Hospital, University Health Network, Toronto, Ontario, Canada

${ }^{7}$ Department of Laboratory Medicine and Pathobiology, University of Toronto, Toronto, Ontario, Canada

${ }^{8}$ Public Health Ontario Laboratory, Toronto, Ontario, Canada

Contributors Conception and design: TF, TM, TAC. Data collection: TF, SBK, JK, TAC. Analysis and interpretation: TF, SBK, JK, TAC. First manuscript draft: TF. Critical revisions of the manuscript: TF, SBK, JK, SRE-D, TM, TAC. Obtained funding: JK, TAC. Overall responsibility: TF, TAC.

Funding This work was funded through a Collaborative Research Agreement with the Public Health Agency of Canada. The authors did not receive non-governmental support.

Competing interests None declared.

Patient consent for publication Not required. 
Provenance and peer review Not commissioned; externally peer reviewed.

Supplemental material This content has been supplied by the author(s). It has not been vetted by BMJ Publishing Group Limited (BMJ) and may not have been peer-reviewed. Any opinions or recommendations discussed are solely those of the author(s) and are not endorsed by BMJ. BMJ disclaims all liability and responsibility arising from any reliance placed on the content. Where the content includes any translated material, BMJ does not warrant the accuracy and reliability of the translations (including but not limited to local regulations, clinical guidelines, terminology, drug names and drug dosages), and is not responsible for any error and/or omissions arising from translation and adaptation or otherwise.

Open access This is an open access article distributed in accordance with the Creative Commons Attribution Non Commercial (CC BY-NC 4.0) license, which permits others to distribute, remix, adapt, build upon this work non-commercially, and license their derivative works on different terms, provided the original work is properly cited, appropriate credit is given, any changes made indicated, and the use is non-commercial. See: http://creativecommons.org/licenses/by-nc/4.0/.

ORCID iD

Tina Felfeli http://orcid.org/0000-0002-0927-3086

\section{REFERENCES}

1 Arora R, Goel R, Kumar S, et al. Evaluation of SARS-CoV-2 in tears of patients with moderate to severe COVID-19. Ophthalmology 2021;128:494-503.

2 Sawant OB, Singh S, Wright RE, et al. Prevalence of SARS-CoV-2 in human post-mortem ocular tissues. Ocul Surf 2021:19:322-9.

3 Edington M, Ramaesh K, Lockington D. Virucidal benefits of povidone-iodine use on the ocular surface: a review. BMJ Open Ophthalmol 2020;5:e000509.

4 Cutts TA, ljaz MK, Nims RW, et al. Effectiveness of Dettol antiseptic liquid for inactivation of Ebola virus in suspension. Sci Rep 2019;9:1-8.

5 Cutts TA, Robertson C, Theriault SS, et al. Assessing the contributions of inactivation, removal, and transfer of Ebola virus and vesicular stomatitis virus by disinfectant Pre-soaked wipes. Front Public Health 2020;8:1-11.

6 ASTM E1052-20. standard practice to assess the activity of microbicides against viruses in suspension 2020.

7 Reed L, Muench H. A simple method of estimating fifty percent endpoints. Am J Hyg 1938;27:493-7.

8 Khan MM, Parab SR, Paranjape M. Repurposing $0.5 \%$ povidone iodine solution in otorhinolaryngology practice in Covid 19 pandemic. Am J Otolaryngol 2020;41:102618. 